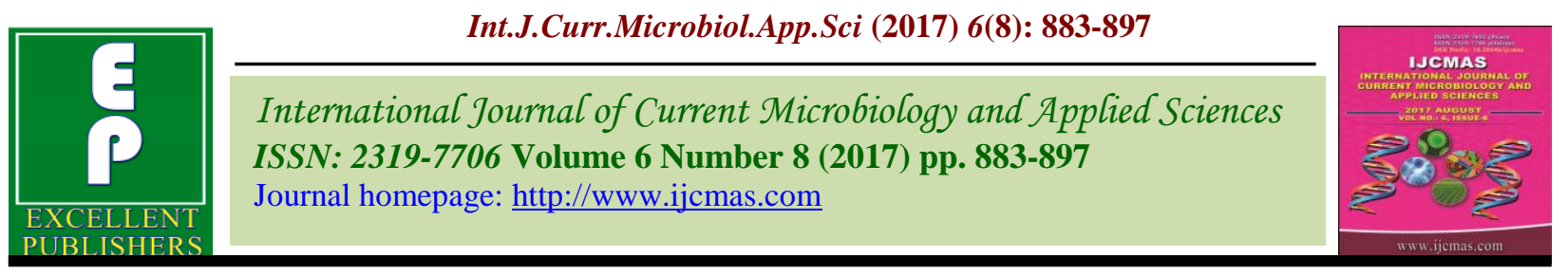

Original Research Article

https://doi.org/10.20546/ijcmas.2017.608.111

\title{
Characterization of ACC Deaminase producing B. cepacia, C. feurendii and S. marcescens for Plant Growth Promoting activity
}

\author{
A. Maxton ${ }^{1}$, P. Singh ${ }^{1}$, S.M. Prasad ${ }^{1}$, Aruna Andy ${ }^{2}$ and S. A. Masih ${ }^{3} *$ \\ ${ }^{1}$ Department of Molecular \& Cellular Engineering, ${ }^{2}$ Directorate of Research, ${ }^{3}$ Centre for \\ Transgenic Studies, Sam Higginbottom University of Agriculture, Technology and Sciences, \\ Allahabad, U.P. India, 211007 \\ *Corresponding author
}

\section{A B S T R A C T}

Finding solutions to global issues like food security entails greater use of chemicals fertilizers, pesticides, fungicides etc. posing serious risks of soil salinity, heavy metal bioaccumulation. PGPR produce enzyme ACC deaminase which degrades (ACC) 1-

Keywords

PGPR

characterization, ACC deaminase, Ninhydrin assay, Plant growth.

Article Info

Accepted:

14 June 2017

Available Online:

10 August 2017 aminocyclopropane-1-carobylic acid the immediate precursor of the plant growth hormone ethylene, into $\alpha$-ketobutyrate and ammonia, thus lowering the level of ethylene in a developing or stressed plant. In the present study, three rhizobacterial strains were isolated from rhizospheric soil of mustard plant in Allahabad region. On the basis of morphological, biochemical, molecular characterization, these isolates were identified as Burkholderia cepacia, Citrobacter feurendii I and Serratia marcescens. The 16S rRNA gene sequences of B. cepacia, and S. marcescens, C. feurendii were submitted to NCBI GenBank under accession numbers LC169488, LC169489, LC169490, respectively, followed by their phylogenetic analysis predicting significant sequence homology with related sequences of NCBI Gene bank. After isolation ACC Deaminase enzyme was partially purified and molecular weight was determined 35-42 kDa. Screeningthe rhizobacterial isolates for plant growth promoting traits (ACC deaminase activity assay; Ninhydrin assay; Phosphate solubilization assay; Production of Siderophore, IAA, Gibberellic Acid, HCN, Ammonia) revealed thatS. marcescens, $C$. feurendii and $B$. cepacia are capable of producing ACC deaminase and solubilizing phosphate along with exhibiting various other plant promoting traits.

\section{Introduction}

For addressing serious global issues like food security, environmental problems caused either directly or indirectly by the use of fertilizers, pesticides, herbicides, and fungicides are of public concern. Since fertilizer management is considered as one of the main factors of sustainable agriculture, gradual replacement of chemical fertilizers with biological fertilizers is quite inevitable since biofertilizers are environment friendly and cost-effective (Tariq et al., 2017). Elucidating non-chemical control methods to reduce postharvest decay is becoming increasingly important. Plant nutrients are essential for the production of crops and healthy food for the world's expanding population (Moustaine et al., 2017). Naturally occurring antagonists on host surfaces are a promising component of biological crop protection (Mazharr et al., 2016).This has 
developed an urge to find alternatives to these established chemical strategies for facilitating plant growth. Ideally, replacements for the chemicals that are currently in widespread use should not only enhance plan1growth, but should also inhibit plant pathogens. One potential alternative may be the use of plant growth-promoting bacteria (Glick et al., 1999). These plant growth promoting bacteria may bind to either roots as rhizospheric bacteria, leaves as phyllospheric bacteria, or they may exist within plant tissues as endophytes. Bacteria able to colonize plant root systems and promote plant growth are referred to as plant growth promoting rhizobacteria (Rubin et al., 2017). The highest concentrations of these microorganisms typically exists around the roots, in the rhizosphere, most probably due to the high levels of nutrients exuded from the roots of many plants that can be utilized by bacteria to support their growth (Whipps, 1990).

Many plant growth-promoting bacteria have been isolated till date, each with one or more traits that might enhance plant growth, under the appropriate conditions. Some of these bacteria may influence plant growth directly by synthesizing plant hormones or facilitating uptake of nutrients from the soil, fixing atmospheric nitrogen that is transferred to the plan, produce siderophores that chelate iron and make it available to the plant root, solubilize minerals such as phosphorus, produce phytohormones and synthesize some less well characterized low molecular mass compounds or enzymes that can modulate plant growth., while others may exert their beneficial effects indirectly via biological control (Glick, 1995). During the process of symbiotic nitrogen-fixation, rhizobacteria convert atmospheric dinitrogen $\left(\mathrm{N}_{2}\right)$ to ammonium $\left(\mathrm{NH}_{3}\right)$, which is further utilized by host legume plants. Plant growth promoting rhizobacteria (PGPR) are a heterogeneous group of bacteria that can be found in the rhizosphere, in association with roots (Ahmad et al., 2011). Ethylene plays a prominent role in the normal growth of higher plants, yet elevated levels of ethylene produced under stress conditions can have a negative impact on plant growth (Glick et al., 1998). Plant cells consume some of the Indole acetic acid that is secreted by the bacteria, together with the endogenous plant hormone IAA that is capable of stimulating plant cell proliferation, elongation along with induction of the synthesis of the enzyme 1aminocyclopropane-1-carboxylate (ACC) synthase.

Some of the ACC, already present or newly synthesized by the plant, is exuded and taken up by the ACC deaminase-containing bacteria (Glick et al., 1998) and this enzyme ACC deaminase (E.C. 3.5.99.7) cleaves ACC, the immediate precursor of ethylene in plants, to form ammonia and $\alpha$-ketobutyrate, both of which are readily metabolized by the bacteria. Direct interaction of ACC with plant significantly increased plant root and shoot length, an increase in biomass and protection of plants from inhibitory effects of ethylene synthesized as a direct consequence of a variety of biotic and abiotic stresses. In some studies, it was suggested that the decrease in nodulation was due to an inhibition in root growth by ethylene (Frankenberger and Arshad, 1995).

In the present study B. cepacia, S. marcescens and $C$. feurendii strains were isolated from the rhizospheric soil of mustard plant and identified on the basis of morphological, biochemical, molecular characterization. 16s rRNA gene sequences of $B$. cepacia, $S$. marcescens, $C$. feurendii were submitted to NCBI Gene Bank under the accession numbers LC169488, LC169489, LC169490 respectively. The isolates were screened for plant growth promoting traits; ACC deaminase activity assay; Ninhydrin assay; 
Phosphate solubilization assay and Production of Siderophore, IAA, Gibberellic Acid, HCN, Ammonia. ACC deaminase enzyme was partially purified by silica gel based column chromatography and its molecular mass was determines using SDS PAGE, recorded as 35$42 \mathrm{kDa}$. S. marcescens, $C$. feurendii and $B$. cepacia were found capable of ACC deaminase activity, phosphate solubilization along with various other plant promoting traits, thereby reported to be promising for increased plant productivity.

\section{Materials and Methods}

\section{Isolation of rhizobacterial strains}

Soil sample was collected from the rhizosphere of mustard plant in the agriculture farms of SHUATS, Allahabad in the month February by uprooting, bulk soil was removed by gently shaking the plants and the rhizosphere soil was collected by dipping the roots in sterile normal saline followed by shaking for $30 \mathrm{~min}$ (Ali et al., 2014) The soil suspension was serially diluted and appropriate dilutions were inoculated on selective medium (Himedia) for Burkholderia cepacia, Citrobacter feurndii and Serratia marcescens, by spread plate technique. The plates were incubated at $35 \pm 2{ }^{\circ} \mathrm{C}$ and identical colonies were selected for further morphological and biochemical studies. Several biochemical tests viz. IMVIC, Citrate utilization, Oxidase, Urease, ONPG, Carbohydrate fermentation etc. were performed for the biochemical characterization of selected rhizobacterial isolates using standard procedures according to Bergey's Manual of Determinative Bacteriology.

\section{Characterization of 16srRNA gene}

For molecular characterization, bacterial genomic DNA was isolated (Chen and Kuo, 1993 ) and quantified at $260 / 280 \mathrm{~nm}$. The
16SrRNA gene was amplified by PCR using forward 5'-CCGAATTCGTCGACAACAGA GTTTGATCCTGGCTCAG-3' and reverse primer 5'-CCCGGGATCCAAGCTTACGGC TACCTTGTTACGACTT-3 primers under standard conditions (initial denaturation $94^{\circ} \mathrm{C}$ for $3 \mathrm{~min}, 35$ cycles of denaturation at $94^{\circ} \mathrm{C}$ for $30 \mathrm{sec}$, annealing at $60^{\circ} \mathrm{C}$ for $30 \mathrm{~s}$, extension at $72^{\circ} \mathrm{C}$ for $60 \mathrm{~s}$, and final extension at $72^{\circ} \mathrm{C}$ for $7 \mathrm{~min}$ ). The PCR product was found the size of 1424, 1487 and 1306 bp for Burkholderia cepacia, Citrobacter feurendii and Serratia marcescens respectively and was purified and sequenced (Applied Biosystems, New Delhi). The sequence of $16 \mathrm{~S}$ rRNA genes of all three isolates were obtained and compared with the existing database of $16 \mathrm{~S}$ rRNA gene and submitted to GenBank of NCBI.

\section{Screening of Rhizobacteria for plant growth promoting traits}

\section{ACC deaminase assay}

ACC deaminase assay was performed according to (Ali et al., 2014) and concentration of $\alpha$-ketobutyrate in each sample was determined by comparison with a standard curve generated as follows: $500 \mu \mathrm{l} \alpha$ ketobutyrate solutions of $0,0.01,0.05,0.1$, $0.2, \quad 0.5,0.75$ and $1 \mathrm{mM}$ were mixed respectively with $400 \mu \mathrm{l}$ of $0.56 \mathrm{~N} \mathrm{HCl}$ and $150 \mu \mathrm{l}$ DNF solution. One ml of $2 \mathrm{~N} \mathrm{NaOH}$ was added and the absorbance at $540 \mathrm{~nm}$ was determined as described above. The optical density values for the different concentrations of ACC deaminase were plotted against different concentrations of $\alpha$-ketobutyrate to generate a standard curve.

\section{Production of Indole Acetic Acid (IAA)}

Nutrient Agar broth amended with 5-mmol tryptophan was inoculated with overnight raised selected bacterial cultures $(0.5 \mathrm{OD}$ at $600 \mathrm{~nm}$ ) and incubated at $28^{\circ} \mathrm{C}$ for $48 \mathrm{~h}$. One 
$\mathrm{ml}$ of culture was centrifuged at 3,000 rpm for $20 \mathrm{~min}$ and supernatant was separated. To the supernatant, $4 \mathrm{ml}$ of Salkowasky reagent was added followed by incubation for $1 \mathrm{~h}$ at room temperature under dark conditions. Absorbance of the pink colour developed was read at $530 \mathrm{~nm}$. Conc. of the proteins in the pellet was determined and the amount of IAA produced was expressed in $\mu \mathrm{g} / \mathrm{mg}$ cell protein (Pandey et al., 2013).

\section{Gibberellic acid production test}

The Rhizobacteria isolates was grown in 100 $\mathrm{ml} \mathrm{NB}$ medium at $30{ }^{\circ} \mathrm{C}$ for $72 \mathrm{~h}$. After incubation isolates were centrifuged at 8,000 rpm for $10 \mathrm{~min}$ and the $\mathrm{pH}$ of supernatant was adjusted to 2.5 using $1 \mathrm{~N} \mathrm{HCl}$ and it was extracted with equal volume of ethyl acetate in a separating funnel. The extract was retreated with equal volume of ethyl acetate 2 to 3 times to get concentrated amount of Gibberellic acid. To $1.5 \mathrm{ml}$ of extract $0.2 \mathrm{ml}$ of potassium ferrocyanide was added and centrifuged at $1,500 \mathrm{~g}$ for $10 \mathrm{~min}$. An equal volume of $30 \% \mathrm{HCl}$ was added in the supernatant and incubated for $1 \mathrm{~h}$ at room temperature. The absorbance of the mixture was measured at $254 \mathrm{~nm}$ in a UV-Visible spectrophotometer. The amount of Gibberellic acid was calculated from the standard curve prepared in range of $10-100 \mu \mathrm{g} \mathrm{ml}^{-1}$ (Holbrok et al., 1961).

\section{Standard colorimetric ninhydrin assay}

Five hundred milligrams of ninhydrin and 15 $\mathrm{mg}$ of ascorbic acid were dissolved in $60 \mathrm{ml}$ of ethylene glycol, stored at ) $20^{\circ} \mathrm{C}$ and mixed with $60 \mathrm{ml}$ of $1 \mathrm{~mol} \mathrm{l}$ ) 1 citrate buffer ( $\mathrm{pH} \mathrm{6.0)}$ prior to use to prepare working ninhydrin reagent. The DF-ACC medium (with an ACC concentration of $3.0 \mathrm{mmoll}^{-1}$ was diluted with the DF medium to respective ACC working concentrations of $0.005,0.01,0.015,0.02$, $0.03,0.04,0.05,0.10,0.15,0.20,0.25,0.30$,
0.40 and $0.50 \mathrm{mmoll}^{-1}$. After the addition of 1 $\mathrm{ml}$ of ACC working solution and $2 \mathrm{ml}$ of ninhydrin reagent, glass test tubes were capped and shaken and placed in a boiling water bath. After $15 \mathrm{~min}$, the tubes were moved into a water bath at room temperature for $2 \mathrm{~min}$ and then shaken for 30s (Lamothe and McCormick, 1972) After standing at room temperature for $10 \mathrm{~min}$, the solution was transferred into a cuvette and absorbance was measured at $570 \mathrm{~nm}$ with spectrophotometer. The DF medium was used as a blank. Each working solution was run in triplicate. In addition, $1 \mathrm{ml}$ of a tenfold diluted supernatant of a bacterial culture was used to determine ACC in bacterial cultures with the standard ninhydrin assay.

\section{Exopolysaccharide production}

Trypticase soya broth (TSB) with different water potentials $(-0.05,-0.15,-0.30,-0.49$, and $-0.73 \mathrm{MPa}$ ) was prepared by adding appropriate concentrations of polyethylene glycol (PEG 6000) (Ali et al., 2014) and was inoculated with $1 \%$ of overnight raised bacterial cultures in TSB. Three replicates of each isolate with each concentration were prepared. After incubation at $28^{\circ} \mathrm{C}$ under shaking conditions (120 rpm) for $24 \mathrm{~h}$, growth was estimated by measuring the optical density at $600 \mathrm{~nm}$. The cultures able to grow at maximum stress level were analyzed for their ability to produce EPS under no stress and maximum stress level $(-0.30 \mathrm{MPa})$. Exopolysaccharide was extracted from 3-dayold cultures raised in TSB (15\% PEG 6000 was added to TSB for inducing stress). The culture was centrifuged at 20,000 rpm for 25 min and supernatant was collected and pellets were washed twice with $0.85 \% \mathrm{KCl}$ to completely extract EPS. The possible extraction of intracellular polysaccharides was ruled out by testing the presence of DNA in the supernatant by DPA reagent. Concentration of protein in the supernatant 
was estimated by Bradford's assay. Supernatant was filtered through $0.45 \mu \mathrm{m}$ nitrocellulose membrane and dialyzed extensively against water at $4^{\circ} \mathrm{C}$. The dialysate was centrifuged $(20,000 \mathrm{rpm})$ for 25 min to remove any insoluble material and mixed with 3 volumes of ice-cold absolute alcohol and kept overnight at $4^{\circ} \mathrm{C}$. The precipitated EPS obtained by centrifugation $(10,000 \mathrm{rpm}$ for $15 \mathrm{~min})$ was suspended in water and further purified by repeating the dialysis and precipitation steps. Total carbohydrate content in the precipitated EPS was determined.

Several another plant growth promoting tests viz. Siderophore (Ali et al., 2014), HCN (Ali et al., 2014), Chitinase (Vyas and Deshpande, 1989), Protease (Pandey et al., 2013), Phosphate solubilization (Gaur, 1990), Cellulase (Samanta et al., 1989) and Lipase (Cowan, 1974) production were performed for better understanding of selected rhizobacterial strains

\section{Characterization of partially purified ACC deaminase enzyme}

ACC deaminase assay was and purification was done by ammonium sulfate precipitation method followed by dialysis (Verma et al., 2011) Silica based column chromatography was performed from dialysis sample by Plugging a Pasteur pipette with a small amount of cotton; a wood applicator stick was used to tamp it down lightly. Silica gel (10gm) was taken and mixed in Sodium phosphate buffer properly and pour the gel in Pasteur pipette using a $10 \mathrm{ml}$ beaker. Column was left for 20-25 min till the Silica gel settles down completely. After the silica gel completely settles down, buffer and gel gets separated. Now the buffer was allowed to flow drop by drop down the column. The solvent level was monitored, both as it flows through the silica gel and the level at the top till the $3 \mathrm{~mm}$ layer was left over the silica gel. After the sample was poured completely it was allowed to stand for $10 \mathrm{~min}$. so that our sample settles down at the bottom of the silica gel. The pure sample was collected at the end of this process at different conc.

\section{Protein concentrations determination}

The protein concentration of toluenized cells was determined by Lawry method. A $26.5 \mu \mathrm{l}$ aliquot of the toluene-labilized bacterial cell sample used for the ACC deaminase enzyme assay was diluted with $173.5 \mu \mathrm{l}$ of $0.1 \mathrm{M}$ Tris$\mathrm{HCl}(\mathrm{pH} 8.0)$, and boiled with $200 \mu \mathrm{l}$ of $0.1 \mathrm{~N}$ $\mathrm{NaOH}$ for 10 min. After the cell sample was cooled to room temperature, the protein concentration was determined by measuring the absorbance at $660 \mathrm{~nm}$ immediately. Bovine serum albumin (BSA) was used to establish a standard curve.

\section{Estimation of molecular weight}

Estimation of molecular weight was done by SDS PAGE electrophoresis of five fractions of different densities from all three bacterial isolates and gel was run at $60 \mathrm{~V}$ till dye reached the end of the gel. After destaining clear bands of protein were seen and compared to corresponding bands of ladder $(1 \mathrm{~Kb})$ to determine the molecular weight of the protein by SDS-PAGE (Laemmli, 1970)

\section{Results and Discussion}

\section{Isolation and biochemical characterization of isolates}

Three rhizobacterial strains of $B$. cepacia, $C$. feurendii and $S$. marcescens were isolated from rhizospheric soil, by spread plate inoculation technique on selective media. (Table 1) (Yabuuchi et al., 2000). A previous study reported that 10 out of 11 cadmiumtolerant bacterial strains isolated from the root 
zone of Indian mustard showed ACC deaminase activity and all 10 strains of these promoted root length significantly (Belimov et al., 2005).

\section{Amplification of 16s rRNA gene}

Quantitative analysis of isolated genomic DNA was performed and the concentrations were recorded as $1.53 \mu \mathrm{g} / \mathrm{ml}$ for $B$. cepacia, $1.38 \mu \mathrm{g} / \mathrm{ml}$ for $S$. marcescens and $1.35 \mu \mathrm{g} / \mathrm{ml}$ for $C$. feurendii. Genomic DNA samples of 1424, 1487 and 1306 bp for B. cepacia, C. feurendii and $S$. marcescens respectively were amplified (Fig. 1). B. cepacia, S. marcescens and $C$. feurendii and amplified products were then sequenced for $16 \mathrm{~S}$ ribosomal RNA and submitted to NCBI under accession number ofLC169488, LC169489 and LC169490 respectively. Phylogenetic analysis of these three sequences by comparison with the sequences in the GenBank database indicated that sequences retrieved for our isolates were homologous with databank sequences. In previous study evolutionary relationships among bacteria, including Rhizobia, were estimated through 16S rDNA sequence comparisons and based on the 16S rDNA sequences of the 27 Philom Bios Rhizobia strains which have ACC deaminase activity, 26 are considered to be Rhizobium leguminosarum whereas one strain, number 2 , is Rhizobium gallicum (Duan et al., 2009).

\section{Plant growth promoting activity of selected isolates}

B. cepacia, C. feurendiiand $S$. marcescens were screened for ACC deaminase activity and compared with control strains to calculate enzymatic activity. The concentration of $\alpha$ ketobutyrate for B. cepacia, C. feurendii and $S$. marcescens were recorded to be $0.3841 \mu \mathrm{M}$ $\mathrm{L}^{-1 ;} 0.3629$ and $0.3257 \mu \mathrm{M} \mathrm{L} \mathrm{L}^{-1}$ respectively. ACC Deaminase activity was calculated by plotting curve for $\alpha$ ketobutyrate. ACC deaminase activity of $B$. cepacia, $C$. feurendii and $S$. marcescens $76.82 \mu \mathrm{M} \alpha \mathrm{KB} \mathrm{mg}^{-1} \mathrm{~h}^{-1}$; 72.58 and $65.14 \mu \mathrm{M} \quad \alpha \mathrm{KB} \quad \mathrm{mg}^{-1} \mathrm{~h}^{-1}$ respectively. This data can be supported by another study, in which the frequency of the presence of ACC deaminase is around 65-76 $\mu \mathrm{M} \alpha \mathrm{KB} \mathrm{mg}{ }^{-1} \mathrm{~h}^{-1}$ which is higher compared to the results of previous study on ACC deaminase in Rhizobia (Ma et al., 2003) They also reported that 5 out of 13 tested Rhizobium spp. shown the activity including 4 commercialized strains Rhizobium leguminosarum bv. Viciae 128C53K, 128C53, 128C53G, 99A1. On the other hand, ACC deaminase containing free-living plant growth-promoting bacteria were more commonly found in polluted soil (Belimov et al., 2005). Previous research indicated that one out of five Azospirillum strains isolated from the roots of field-grown plants in Pakistan showed ACC deaminase activity in vitro (Blaha et al., 2006).

When B. cepacia, $C$. feurendii and $S$. marcescens was screened for Indole 3 acetic acid production. The concentrations of IAA for $B$. cepacia, $C$. feurendii and $S$. marcescens were recorded as $4.22 \mu \mathrm{g} / \mathrm{ml} ; 2.42 \mu \mathrm{g} / \mathrm{ml}$ and $1.86 \mu \mathrm{g} / \mathrm{ml}$ respectively (Fig. 2a). Results of previous study reported $41-47 \quad \mu \mathrm{g} / \mathrm{ml}$ concentration of IAA while with species of Pseudomonas. $\quad V$. paradoxus5C-2 also produced indole in vitro (Ali et al., 2014). In another study the production of indole acetic acid varies with bacterial isolates and concentration of tryptophan, although intrinsic ability of microorganism to produce IAA in the rhizosphere depends on the availability of precursors and uptake of microbial IAA by plant (Arshad and Frankenberger, 1993). B. cepacia, $C$. feurendii and $S$. marcescens were tested for gibbrelic acid production. Gibberellic acid concentration in Capsicum annum plants inoculated with bioinoculum of B. cepacia; $S$. marcescens and $C$. feurendiiwas recorded as 
$0.68 \mu \mathrm{g} / \mathrm{ml} ; \quad 0.24 \mu \mathrm{g} / \mathrm{ml}$ and $0.32 \mu \mathrm{g} / \mathrm{ml}$ respectively (Fig. 2b). Our results are in accordance with another study which states that the growth promotion in plants induced by Azospirillum infection, may occur by a combination of both gibberellin production and gibberellin glucoside or glucosyl ester deconjugation by the bacterium (Piccoli et al., 1997) Similar concentration of gibberellins was recorded in cultures of A. brasilense (Janzen et al., 1992).

The absorbance values of ACC solutions ranging from 0.015 to $0.3 \mathrm{~m} \mathrm{~mol} / \mathrm{l}$ ) at $570 \mathrm{~nm}$ after reaction were highly correlated with the ACC concentrations $\left(\mathrm{R}^{2}=0.999\right)$ and resulted in linear calibration curves by standard ninhydrin assay. Conc. of $0.05,0.15$ and 0.25 $\mathrm{mmol} / \mathrm{l}$ was recorded for $S$. marcescen, $C$. feurendii and B. cepacia respectively (Fig. $2 \mathrm{c})$. The absorbance value of each ACC working concentration at $570 \mathrm{~nm}$ in the standard assay was related to previous results of B. cepacia (Li et al., 2011).

Isolates screened for EPS production under both no stressed conditions as well as under minimum water potential $(-0.30 \mathrm{MPa})$. The strain B. cepacia produced maximum amount of EPS $(3.18 \pm 0.02 \mathrm{mg} / \mathrm{mg}$ protein) under non-stressed condition, while and $S$. marcescens produced lesser amount of EPS $(2.76 \pm 0.04$ and $2.01 \pm 0.3 \mathrm{mg} / \mathrm{mg}$ protein respectively). Under drought stress, $B$. cepacia was best isolate since produce $(4.893 \pm 0.06 \mathrm{mg} / \mathrm{mg}$ protein) of EPS followed by $C$. feurendii $(4.23 \pm 0.03 \mathrm{mg} / \mathrm{mg}$ protein) and $S$. marcescens $(3.46 \pm 0.05 \mathrm{mg} / \mathrm{mg}$ protein) (Fig. 2d).

Ali et al., (2014) conducted study on Pseudomonas isolates and found maximum $3.22 \mathrm{mg} / \mathrm{mg}$ protein EPS production (from Rdgp10 strain) while another strain (BriP15) produced $2.18 \mathrm{mg} / \mathrm{mg}$ protein EPS. Glick et al., (1998) established that PGPB that have ACC deaminase activity help plants to withstand stress (biotic or abiotic) by reducing the level of the stress hormone ethylene through the activity of enzyme ACC deaminase, which hydrolyzes ACC into $\alpha$ ketobutyrate and ammonia instead of ethylene (Rubin et al., 2017).

The rhizobacterial isolates of B. cepacia, $C$. feurendii and $S$. marcescens were screened for various indirect plant growth promoting traits: Phospahte solubiolization; Production of Siderophore, HCN, Chtinase, Cellulose, Lipase and Ammonia. These phosphate solubilizing B. cepacia, $C$. feurendii and $S$. marcescens isolates, were screened to be positive for these indirect plant growth promoting traits (Fig. 3a-h) that confirms the ability of these rhizobacterial isolates as potential plant growth promoting agents.

\section{Screening of bacterial isolates for their ability to promote plant growth}

Rhizobacteria exhibit several plant growth promoting characteristics like phosphate solubilization, Nitrogen fixation, production of siderophore, IAA, Ninhydrin and ACC deaminase (Fig. 1, 2, 3) that was supported by study of other son B. cepacia, S. marcescens isolates. The bacteria included in PGPR category are distributed across different taxa comprising of Firmicutes, Acinetobacter, Cyanobacteria, Bacteriodes and Proteobacteria. PGPR can affect plant growth by a wide range of mechanisms such as solubilization of inorganic phosphate, production of phytohormones, siderophore and organic acids, lowering of plant ethylene levels, nitrogen fixation and biocontrol of plant diseases (Singh et al., 2017). 
Table.1 Cultural, morphological and biochemical identification of Burkholderia cepacia, Citrobacter feurendii and Serratia marcescens isolates

\begin{tabular}{|c|c|c|c|c|}
\hline \multirow[t]{3}{*}{$\begin{array}{c}\text { Cultural } \\
\text { characteristics }\end{array}$} & Colour of colony & $\begin{array}{c}\text { opaque light yellow } \\
\text { colonies }\end{array}$ & $\begin{array}{c}\text { Light gray } \\
\text { translucent to } \\
\text { opaque colonies } \\
\text { with glossy surface }\end{array}$ & $\begin{array}{l}\text { Pink to magenta } \\
\text { opaque iridescent } \\
\text { colonies }\end{array}$ \\
\hline & Shape of colony & $\begin{array}{l}\text { Straight rods with } \\
\text { rounded ends }\end{array}$ & $\begin{array}{c}\text { Straight rods } \\
\text { occurring singly or } \\
\text { in pairs }\end{array}$ & $\begin{array}{l}\text { Straight rods with } \\
\text { rounded ends }\end{array}$ \\
\hline & Elevation & convex & convex & convex \\
\hline \multirow{3}{*}{$\begin{array}{l}\text { Morphological } \\
\text { characteristics }\end{array}$} & Gram's reaction & Gram negative & Gram negative & Gram negative \\
\hline & Spore formation & Non-spore forming & Non-spore forming & Non-spore forming \\
\hline & $\begin{array}{l}\text { Arrangement of } \\
\text { cells }\end{array}$ & $\begin{array}{l}\text { Cells occur singly, } \\
\text { rarely in pairs }\end{array}$ & Cells form clusters & Cells form clusters \\
\hline \multirow{12}{*}{ Biochemical } & Indole test & Negative & Negative & Negative \\
\hline & Methyl red test & Negative & Positive & Positive \\
\hline & VP test & Negative & Negative & Positive \\
\hline & Catalase test & Positive & Positive & Positive \\
\hline & $\begin{array}{c}\text { Citrate utilization } \\
\text { test }\end{array}$ & Negative & Positive & Positive \\
\hline & $\begin{array}{c}\text { Nitrate reduction } \\
\text { test }\end{array}$ & Positive & Positive & Positive \\
\hline & $\begin{array}{c}\text { Hydrogen sulphide } \\
\text { test }\end{array}$ & Positive & Positive & Negative \\
\hline & Oxidase test & Negative & Negative & Negative \\
\hline & Urease test & Positive & Positive & Negative \\
\hline & Starch hydrolysis & Negative & Negative & Negative \\
\hline & ONPG & Positive & Positive & Positive \\
\hline & PPA & Positive & Positive & Positive \\
\hline \multirow{13}{*}{$\begin{array}{l}\text { Carbohydrate } \\
\text { Fermentation }\end{array}$} & D-Glucose & Positive & Positive & Positive \\
\hline & Sucrose & Positive & Positive & Positive \\
\hline & Maltose & Positive & Positive & Positive \\
\hline & Lactose & Negative & Positive & Negative \\
\hline & Xylose & Positive & Positive & Negative \\
\hline & D-Mannitol & Negative & Positive & Positive \\
\hline & Raffinose & Positive & Positive & Positive \\
\hline & L-Rhamnose & Positive & Positive & Negative \\
\hline & L-Arabinose & Positive & Positive & Negative \\
\hline & Esculin & Negative & Positive & Positive \\
\hline & L-Arginine & Negative & Positive & Negative \\
\hline & L-Ornithine & Positive & Positive & Positive \\
\hline & L-Lysine & Negative & Negative & Positive \\
\hline
\end{tabular}


Table.2 Homology based study

\begin{tabular}{|c|c|c|c|}
\hline Query value (\%) & $\begin{array}{l}\text { B. } \\
\text { cepacia }\end{array}$ & C. freundii & S. marcescens \\
\hline B. cepacia & 100 & 81 & 77 \\
\hline C. freundii & 77 & 100 & 84 \\
\hline S. marcescens & 85 & 96 & 100 \\
\hline
\end{tabular}

Fig.1 PCR for 16s rRNA gene amplification for isolates(Lane 1: 1kb Ladder, Lane 2: B. cepacia, Lane 4: S. marcescens, Lane 5: C. feurendii)

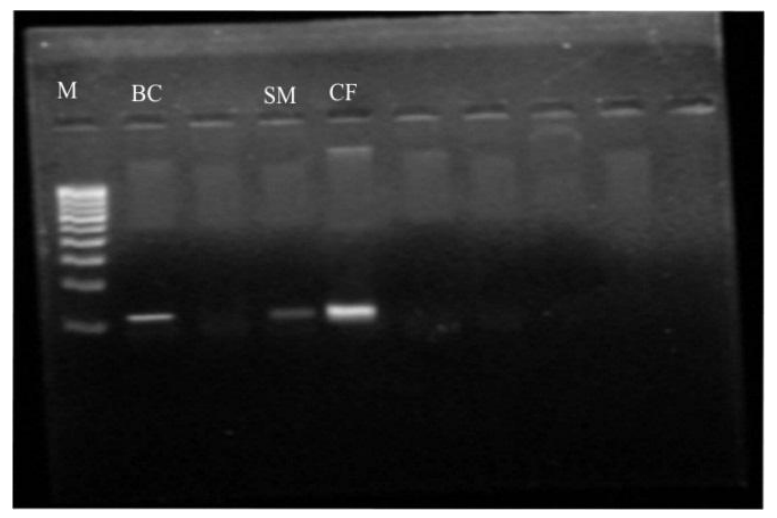

Fig.2 Comparison of ACC Deaminase conc. for (a) Indole acetic acid and (b) Gibberellic acid (c) Ninhydrin assay and (d) Exoploysaccharide production test of isolates

\section{Standard Curve of IAA}

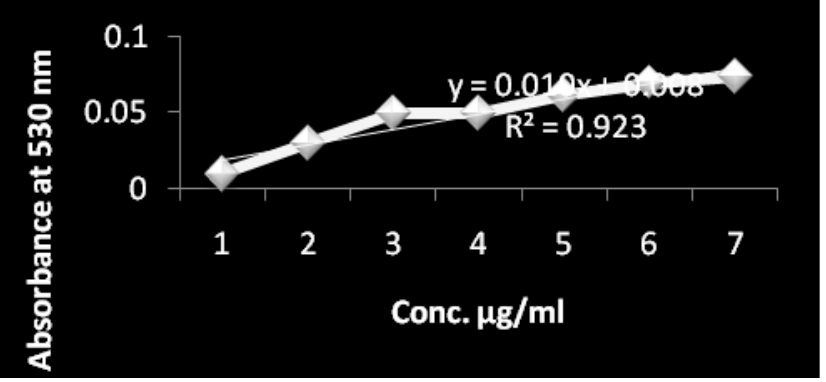

(a)

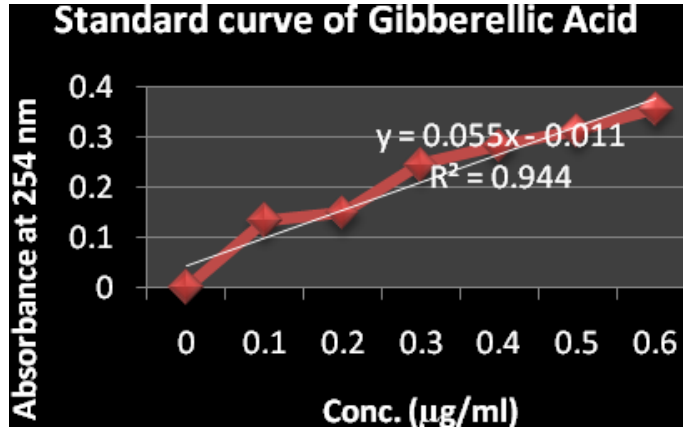

(b) 


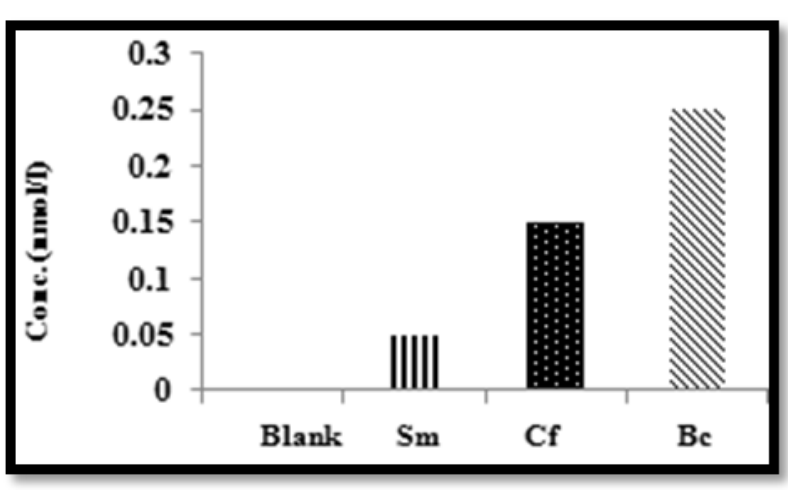

(c)

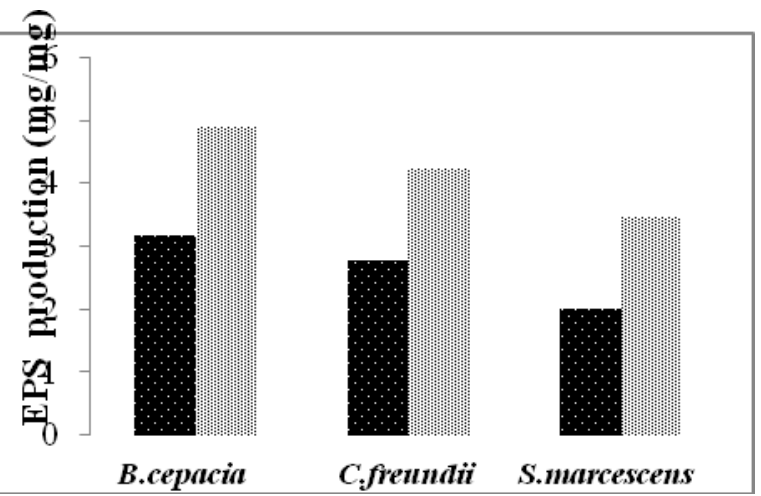

(d)

Fig.3 Plant growth promoting (a) Siderophore production (b) Phosphate solubilisation (c) Nitrogen fixation (d) HCN production (e) Ammonia production (f) Cellulase production (g) Chitinase production and (h) Lipase production test for (a) Control (b) B. cepacia (c) S. marcescens (d) C. freundii

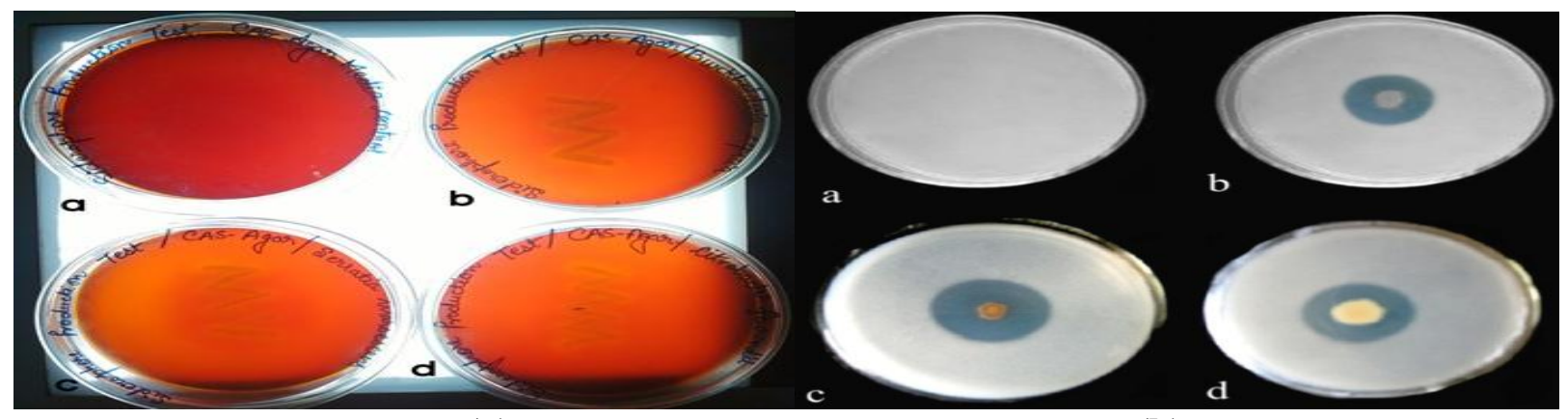

(a)

(b)

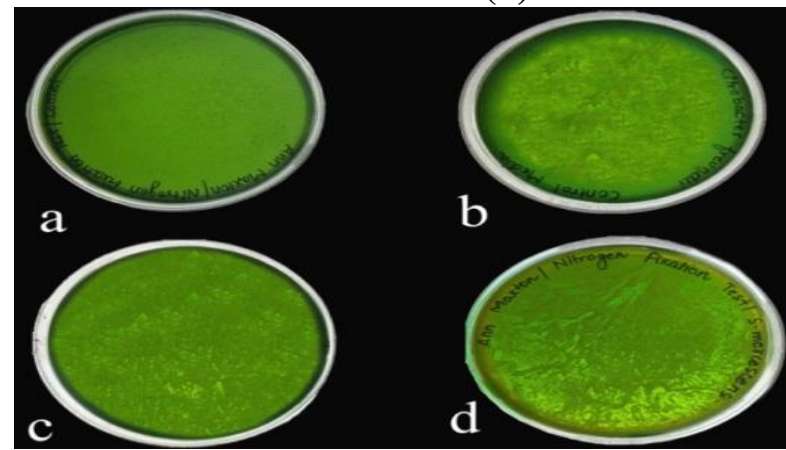

(c)

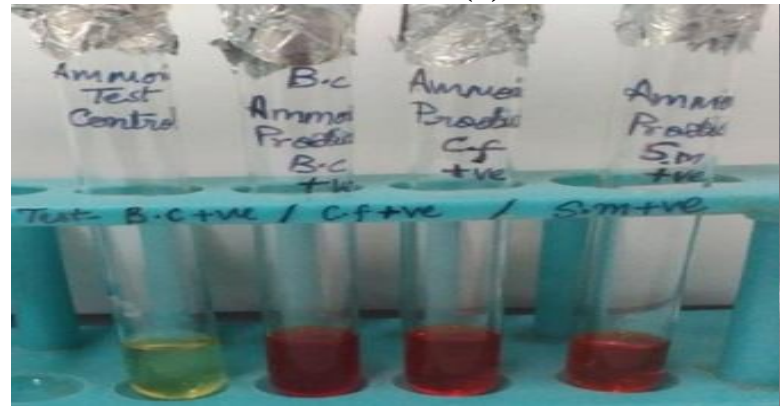

(e)

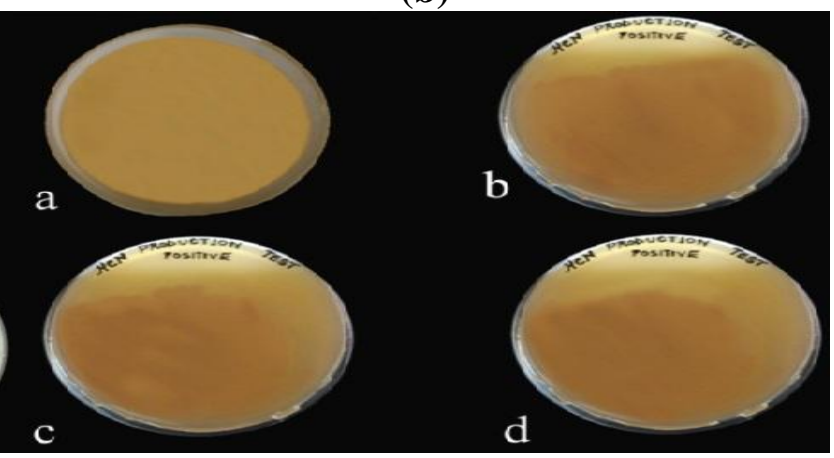

(d)

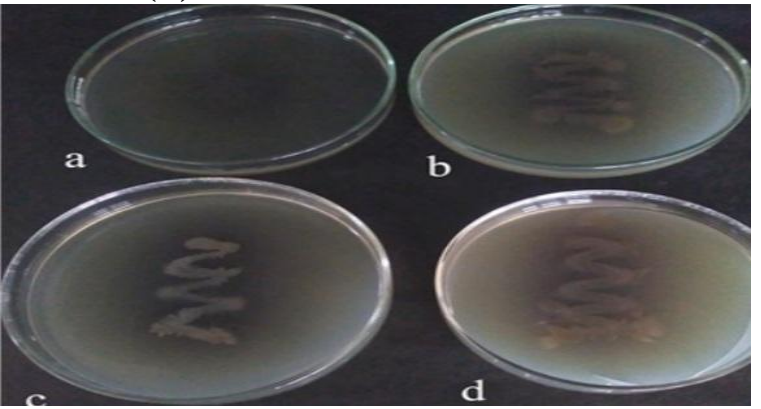

(f) 


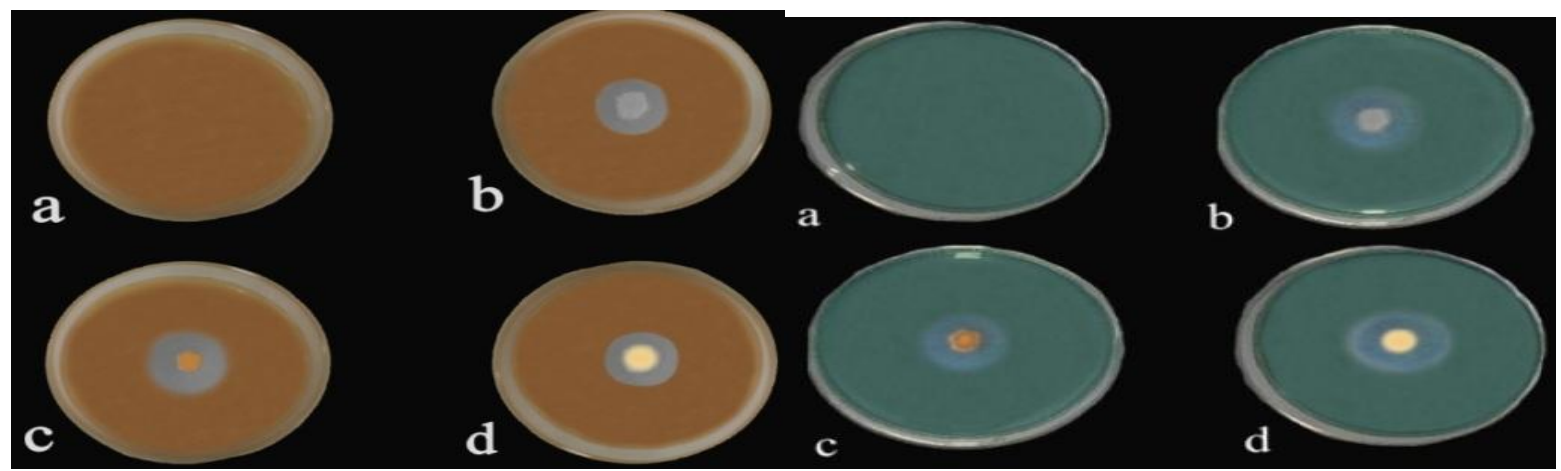

(g)

(h)

Fig.4 Comparison among crude, ammonium sulphate precipitated and column chromatography sample respectively for (a) overall yield (\%) and (b) Specific activity

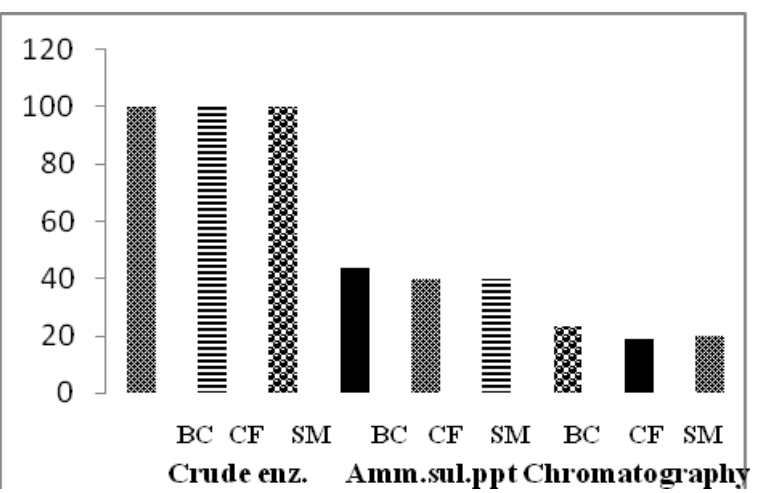

(a)

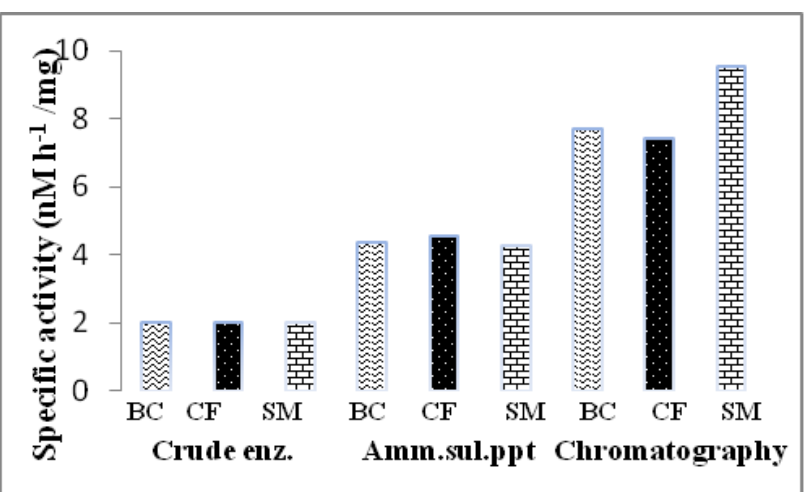

(b)

Fig.5 Molecular determination of purified fractions (five) of ACC deaminase for (a) B. cepacia of $42 \mathrm{KDa}$, (b) C. feurendii of $42 \mathrm{KDa}$ and (c) S. marcescens of $35 \mathrm{KDa}$ protein size

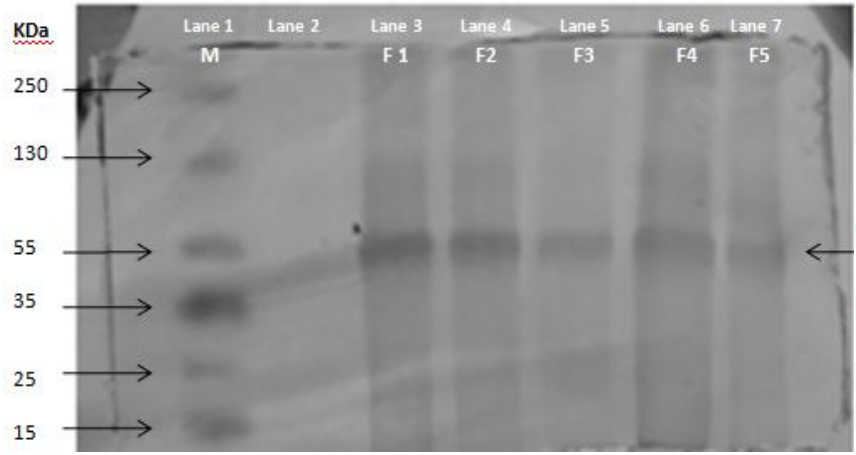

(a)

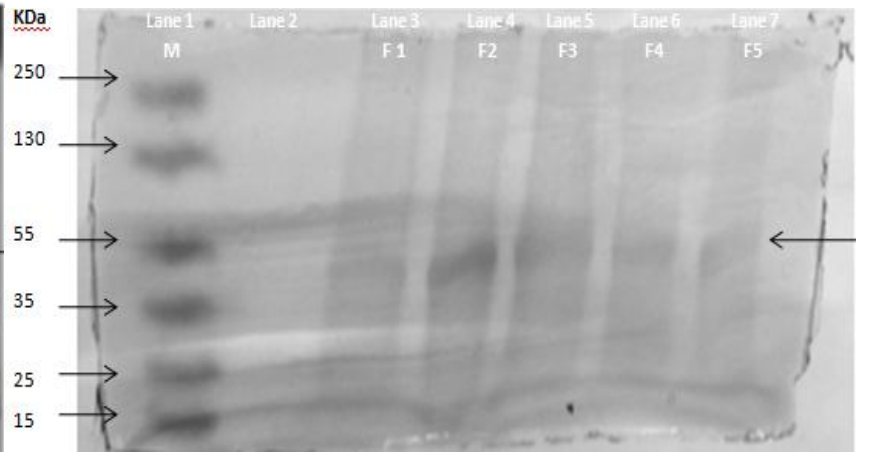

(b) 


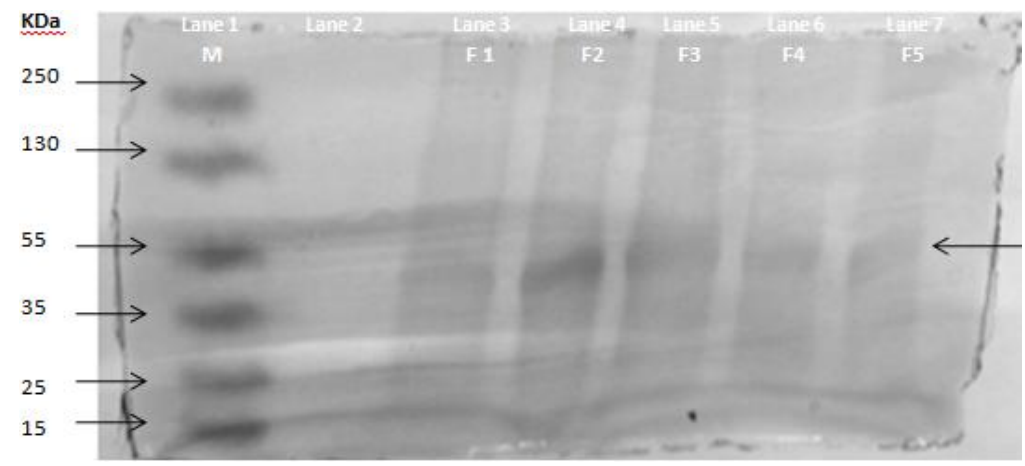

(c)

\section{Characterization of purified ACC deaminase enzyme}

Three different precipitation percentages was selected for ammonium sulphate (30, 50 and $70 \%$ ) and five different fractions were collected during silica gel column chromatography. 9.7, 7.19 and $5.02 \mathrm{mg} / \mathrm{ml}$ average protein conc. was obtained for crude enzyme, after ammonium sulphate precipitation and column chromatography respectively while $B$. cepacia was used as sample. Samples of B. cepacia, $C$. feurendii and $S$. marcescens showed average protein conc. of $9.7,8.4,6.86 \mathrm{mg} / \mathrm{ml}$ for crude samples 7.196 .86 and $6.33 \mathrm{mg} / \mathrm{ml}$ for ammonium sulphate precipitation and 5.02, 4.76 and $3.92 \mathrm{mg} / \mathrm{ml}$ for column chromatography respectively.

Total protein conc., enzyme activity, total activity and specific activity were calculated and observed that specific activity increased after each purification step in all three isolates while sufficient decrease in yield was recorded for all samples. Specific activity of 7.5-9.7 $\mathrm{nM} \mathrm{h}^{-1} / \mathrm{mg}$ was achieved while 23$18 \%$ yield was recorded in selected isolates (Fig. 4a, b).

ACC deaminase enzyme activity assay under both non-stress and drought stress conditions by quantifying the amount of $\alpha$-ketobutyrate produced during the deamination of $\mathrm{ACC}$ by the enzyme ACC deaminase, it was also reported in their study that isolate SorgP4 utilized ACC as a sole source of nitrogen by the production of ACC deaminase enzyme and showed the greater amount of ACC deaminase activity $(3.71 \pm 0.025 \mu \mathrm{M} / \mathrm{mg}$ protein/h of $\alpha$-ketobutyrate) under non-stress and $1.42 \pm 0.039 \mu \mathrm{M} / \mathrm{mg}$ protein $/ \mathrm{h}$ of $\alpha$ ketobutyrate under drought stress condition respectively (Ali et al., 2014).

\section{Molecular weight determination of $\mathrm{ACC}$ Deaminase}

Molecular mass of ACC Deaminase enzyme purified from B. cepacia, C. feurendii and $S$. marcescens were recorded as $42 \mathrm{kDa}, 42 \mathrm{kDa}$ and $35 \mathrm{kDa}$ respectively (Fig. 5a, b, c). Our data is supported by the findings which state that ACC deaminase is a multimeric enzyme (homodimeric orhomotrimeric) with a subunit molecular mass of approximately 35-42 kDa. It is a sulfhydral enzyme in which one molecule of the essential co-factor pyridoxal phosphate (PLP) is tightly bound to each subunit (Glick et al., 1998).

In conclusion, B. cepacia, C. feurndii and $S$. marcescens isolates were screened for plant growth promoting traits: ACC deaminase activity assay; Ninhydrin assay; Phosphate solubilization assay and Production of Siderophore, IAA, Gibberellic Acid, HCN, Ammonia. ACC deaminase producing and phosphate solubilizing $S$. marcescens, $C$. feurendii and B. cepacia isolates, exhibiting 
different plant promoting traits were reported to be promising alternative to the established chemical strategies for increased agricultural productivity. Various direct and indirect plant growth promoting tests revealed that $B$. cepacia possessed highest whereas $S$. marcescens possessed least plant growth promoting potential. There is much exiting work to be done on better understanding the mechanism of PGPR which are capable of sustaining plants under various stress conditions. The ultimate goal of the PGPR isolates in the present study lies in their use as bio fertilizers, which will be cost effective and ecofriendly, thus reducing the bio accumulation of toxic compounds which negatively affects soil biota. The ultimate achievement of these inoculates will be to be used as bio fertilizers that are cost effective and do not hinder soil fertility unlike chemical fertilizers. Further research and understanding of mechanism of PGPR mediated phytostimulation would pave the way to find out more competent rhizobacterial strains which may work under diverse agro-ecological conditions.

\section{References}

Ahmad, M., Zahir, Z.A., Asghar, H.N., and Asghar, M. 2011. Inducing salt tolerance in mung bean through coinoculation with rhizobia and plantgrowth-promoting rhizobacteria containing 1-aminocyclopropane-1carboxylate deaminase. Can. J. Microbiol., 57: 578-589.

Ali, S.Z., Shya, V., and Rao, L.V., 2014. Isolation, characterization of droughttolerant ACC deaminase exopoly saccharide-producing fluorescent Pseudomonas sp. Ann. Microbiol., 5: 493-503.

Arshad, M., and Frankenberger, W.T. 1993. Microbial production of plant growth regulators. Edited by Blaine, F. and
Metting, Jr. Soil Microbiol Eco. Marcel Dekker, Inc., New York, 307-347.

Belimov, A.A., Hontzeas, N., Safronova, V.I., Demchinskaya, S.V., Piluzza, G., Bullitta, S. and Glick, B.R. 2005. Cadmium-tolerant plant growthpromoting bacteria associated with the roots of Indian mustard (Brassica juncea L. Czern.). Soil Biol. Biochem., 37: 241-250.

Blaha, D., Prigent-Combaret, C., Mirza, M.S., Mo“enne-Loccoz, Y. 2006. Phylogeny of the 1-aminocyclopropane-1carboxylic acid deaminase encoding gene $a c d S$ in phytobeneficial pathogenic Proteobacteria relation with strain biogeography. FEMS Microbiol. Ecol., 56: 455-470.

Chen, W.P. and Kuo, T.T. 1993. A simple and rapid method for the preparation of Gram-negative bacterial genomic DNA. Nucleic Acids Res., 21: 2260.

Cowan, S. 1974. Cowan and Steel's Manual for the identification of medical bacteria, 2nd ed., Cambridge.

Duan, J., Mu“ller, K.M., Charles, T.C., Vesely, S. and Glick, B.R. 20091Aminocyclopropane-1-carboxylate (ACC) deaminase genes in rhizobia from southern Saskatchewan. Microbiol. Ecol., 57: 423-436.

Frankenberger, W.T. and Arshad, M., 1995. Phytohormones in Soils: Microbial Production Function. Marcel Dekker Inc., New York, USA. Pp. 345-347.

Gaur, A. 1990. Physiological functions of phosphate solubilizing microorganisms. Omega Scientific Publishers, New Delhi. Pp. 16-72.

Glick, B.R., Karaturov'ic, D. and Newell, P. 1995. A novel procedure for rapid isolation of plant growth-promoting rhizobacteria. Can. J. Microbiol., 41, 533-536.

Glick, B.R., Patten, C.L., Holguin, G. and Penrose, D.M. 1999. Biochemical and 
Genetic Mechanisms Used by Plant Growth-Promoting Bacteria. Imperial College Press, London.

Glick, B.R., Penrose, D.M. and Li, J. 1998. A model for the lowering of plant ethylene concentrations by plant growth promoting bacteria. J. Theor. Biol., 190: 63-68.

Holbrook, A., Edge, W. and Bailey, F. 1961. Spectrophotometric method for determination of gibberellic acid. $A d v$. Chem. Ser., 28: 159-167.

Janzen, R.A, Rood, S.B., Dormaar, J.F. and McGill, W.B. 1992. Azospirillum brasilense produces gibberellin in pure culture on chemical-defined medium in co-culture on straw. Soil Biol. Biochem., 24: 1061-1064.

Laemmli, U.K. 1970. Cleavage of structural proteins during the assembly of the head of bacteriophage T4. Nature, 227: 680685.

Lamothe, P.J., and McCormick, P.G. 1972. Influence of acidity on the reaction of ninhydrin with amino acids. Anal. Chem., 44: 821-825.

Li, Z., Chang, Z., Lin, L., Li, Y., and An, Q. 2011. A colorimetric assay of 1 -amino cyclopropane-1-carboxylate (ACC) based on ninhydrin reaction for rapid screening of bacteria containing ACC deaminase. Lett. Appl. Microbiol., 53: 178-185.

Ma, W., Guinel, F.C., and Glick, B.R. 2003. Rhizobium leguminosarum biovar viciae 1- aminocyclopropane-1-carboxylate deaminase promotes nodulation of pea plants. Appl. Env. Microbiol., 69: 43964402.

Mazhar, R., Qureshi, H., Ilyas, N., and Shabir, S. 2016. Plant growth promoting Rhizobacteria: Biocontrol potential for pathogens, Pure Appl. Biol., 5: 12881295.

Moustaine, M., Elkahkahi, R., Benbouazza, A., Benkirane R., Achbani, E. 2017.
Effect of plant growth promoting rhizobacterial (PGPR) inoculation on growth in tomato (Solanum Lycopersicum L.) and characterization for direct PGP abilities in Morocco. Int. J. Env. Agri. Biotechnol., 2: 590-595.

Pandey, S., Ghosh, P.K., Ghosh, S., De, T.K., and Maiti, T.K. 2013. Role of Heavy metal resistant Ochrobactrum spp. And Bacillus Spp. Strains in bioremediation of a rice cultivar and their PGPR like activities. J. Microbiol., 51: 11-17.

Piccoli, P., Lucangeli, C.D., Schneider, G., and Bottini, R. 1997. Hydrolysis of [17,17- $\left.2 \mathrm{H}_{2}\right]$ gibberellin A20-glucoside [17,17- $2 \mathrm{H}_{2}$ ] gibberellin A20-glucosyl ester by Azospirillum lipoferum cultured in a nitrogen-free biotin based chemically-defined medium. Plant Growth Reg., 23: 179-182.

Rubin, R., Groenigen, K., and Hungate, B. 2017. Plant growth promoting rhizobacteria are more effective under drought: a meta-analysis. Plant Soil, doi: 10.1007/s11104-017-3199-8

Samanta, R., Pal, D., and Sem, S. 1989. Production of hydrolases by N2-fixing microorganisms, Biochemie und Physiologie der Pflanzen, 185: 75-81.

Singh, R., Pandey, K., Kumar, A., and Singh, M. 2017. PGPR Isolates from the Rhizosphere of Vegetable Crop Momordica charantia: Characterization and Application as Biofertilizer, Int. J. Curr. Microbiol. Appl. Sci., 6: 17891802.

Tariq, M., Noman, M., Ahmed, T., Hameed, A., Manzoor, N., and Zafar, M. 2017. Antagonistic features displayed by Plant Growth Promoting Rhizobacteria (PGPR): A Review, J. Plant Sci. Phytopathol., 1: 38-43.

Verma, O.P., Ojha, K., Bailey, S.B., Singh, P.K., Dubey, R., and Mishra, B.N., 2011. Isolation, partial purification characterization of phospholipid 
hydroperoxide Glutathione peroxidase from Oryza sativa seedlings. J. Chem. Eng. Process Technol., 2, 1-5.

Vyas, P., and Deshpande, M. 1989. Chitinase production by Myrothecium verrucaria and its significance for fungal mycelia degradation, J. Gen. Appl. Microbiol., 35: 343-350.

Whipps, J.M. 1990. Carbon utilization: The Rhizosphere. Wiley Interscience,
Chichester, U.K., 59-97.

Woese, C. 1987. Bacterial Evolution, Microbiol. Rev., 51: 221-271.

Yabuuchi, E., Kawamura, Y., Ezaki, T., Ikedo, M., Dejsirilert,, S., and Fujiwara, N. 2000. Burkholderia uboniae sp. nov., L-arabinose-assimilating but different from Burkholderia thailensis and Burkholderia vietnamiensis. Microb. Immunol., 44: 307-317.

\section{How to cite this article:}

Maxton, A., P. Singh, S.M. Prasad, Aruna Andy and Masih, S.A. 2017. Characterization of ACC Deaminase Producing B. cepacia; C. feurendii and S. marcescens for Plant Growth Promoting activity. Int.J.Curr.Microbiol.App.Sci. 6(8): 883-897. doi: https://doi.org/10.20546/ijcmas.2017.608.111 